\title{
Kitasatospora viridis sp. nov., a novel actinomycete from soil
}

\author{
Zhiheng Liu, ${ }^{1}$ Carlos Rodríguez, ${ }^{2}$ Liming Wang, ${ }^{1}$ Quingfeng Cui, ${ }^{1}$ \\ Ying Huang, ${ }^{1}$ Erika T. Quintana ${ }^{2}$ and Michael Goodfellow ${ }^{2}$ \\ ${ }^{1}$ State Key Laboratory of Microbial Resources, Institute of Microbiology, Chinese Academy of \\ Sciences, Beijing 100080, People's Republic of China \\ ${ }^{2}$ School of Biology, University of Newcastle, Newcastle upon Tyne NE1 7RU, UK
}

Correspondence

Michael Goodfellow

m.goodfellow@ncl.ac.uk
The genus Kitasatospora (originally Kitasatosporia) was proposed by Ōmura et al. (1982); its members were transferred to the genus Streptomyces by Wellington et al. (1992), and the genus was re-established by Zhang et al. (1997). The taxon is now widely recognized and encompasses 18 species: Kitasatospora arboriphila Groth et al. 2004, K. azatica (Nakagaito et al. 1993a) Zhang et al. 1997, K. cheerisanensis Chung et al. 1999, K. cineracea Tajima et al. 2001, K. cochleata (Nakagaito et al. 1993a) Zhang et al. 1997, K. cystarginea Kusakabe and Isono 1992, K. gansuensis Groth et al. 2004, K. griseola Takahashi et al. 1985, K. kifunensis (Nakagaito et al. 1993b) Groth et al. 2003, K. mediocidica Labeda 1988, K. niigatensis Tajima et al. 2001, K. nipponensis Groth et al. 2004, K. paracochleata (Nakagaito et al. 1993a) Zhang et al. 1997, K. paranensis Groth et al. 2004, K. phosalacinea Takahashi et al. 1985, K. putterlickiae Groth et al. 2003, K. setae Ōmura et al. 1983 [species name corrected by Ōmura et al. (1985)], the type species, and $K$. terrestris Groth et al. 2004.

An actinomycete isolate, strain $52108 \mathrm{a}^{\mathrm{T}}$, was isolated from rhizosphere soil $[\mathrm{pH} 4 \cdot 4-4 \cdot 5$, as determined using the method of Reed \& Cummings (1945)] of wild tea plants (Camellia oleifera) growing on the campus of Jiangxi

Published online ahead of print on 3 December 2004 as DOI 10.1099/ ijs.0.63329-0.

The GenBank/EMBL/DDBJ accession number for the 16S rRNA gene sequence of strain $52108 a^{\top}$ is AY 613990 .
Agricultural University, Jiangxi Province, China. Soil suspensions prepared using a dispersion and differential centrifugation procedure (Wang et al., 2003) were plated onto an acidified selective isolation medium supplemented with actidione and nystatin (Huang et al., 2004) and the preparations were incubated at $28^{\circ} \mathrm{C}$ for 3 weeks. The organism was maintained on oatmeal agar (ISP medium 3; Küster, 1959) slants, adjusted to $\mathrm{pH} 5 \cdot 5$, at $4{ }^{\circ} \mathrm{C}$ and as suspensions of spores in glycerol $(20 \%, \mathrm{v} / \mathrm{v})$ at $-20^{\circ} \mathrm{C}$.

Spore chain morphology was observed on acidified oatmeal agar following incubation for 2 weeks at $28{ }^{\circ} \mathrm{C}$, using the coverslip technique of Kawato \& Shinobu (1959); growth on the coverslip was fixed and examined following the methods of Zhou et al. (1998). Spore surface ornamentation was observed by examining gold-coated, dehydrated specimens using a Cambridge Stereoscan 240 scanning electron microscope following the procedure described by O’Donnell et al. (1993). Spore suspensions for biochemical, degradative, nutritional and physiological tests were prepared using the procedure described by Hopwood et al. (1985) and the tests were carried out using media and methods described by Williams et al. (1983). Strain $52108 \mathrm{a}^{\mathrm{T}}$ and $K$. paracochleata strain DSM $41656^{\mathrm{T}}$ were examined for their ability to grow on oatmeal agar adjusted to $\mathrm{pH} 3 \cdot 5$, $4 \cdot 5,5 \cdot 5,6 \cdot 5,7 \cdot 0$ and $8 \cdot 0$ using a citric acid/disodium hydrogen phosphate buffer system (McIlvaine, 1921).

Biomass for chemotaxonomic studies was grown in shake flasks of modified Bennett's broth (Jones, 1949), adjusted 
to $\mathrm{pH} 5 \cdot 0$, and incubated at $28{ }^{\circ} \mathrm{C}$ for 7 days. After centrifugation, the biomass was washed in distilled water and Tris/EDTA (0.03 M Tris/HCl, 0.1 M EDTA, pH 8.0) and stored at $-20{ }^{\circ} \mathrm{C}$ until required. Standard chromatographic procedures were used to determine the diagnostic isomers of diaminopimelic acid (Staneck \& Roberts, 1974), the acyl type of muramic acid (Uchida \& Aida, 1977) and menaquinone (Collins, 1985; Wu et al., 1989), polar lipid (Minnikin et al., 1984) and whole-organism sugar patterns (Hasegawa et al., 1983), using appropriate reference strains as controls. Non-hydroxylated fatty acids were extracted, purified, methylated, identified and quantified by GC using the standard Microbial Identification System (MIDI; Sasser, 1990; Kämpfer \& Kroppenstedt, 1996).

Extraction of genomic DNA, PCR amplification and direct sequencing of the $16 \mathrm{~S}$ rRNA gene were carried out according to Kim et al. (1998), and the resultant almost complete sequence (1412 nt) was manually aligned with corresponding sequences of representatives of the genera Kitasatospora, Streptacidiphilus and Streptomyces using the pairwise alignment option and the 16S rRNA gene sequence secondary structural information from the PHYDIT program (Chun, 1995). Phylogenetic trees were inferred using the least-squares, maximum-likelihood, maximum-parsimony and neighbour-joining tree-making algorithms from the PHYLIP 3.5c software package (Felsenstein, 1993) and the TREECON program (Van de Peer \& De Wachter, 1994). The resultant unrooted tree topologies were evaluated by bootstrap analyses of the neighbour-joining method, based on 1000 resamplings, using programs from the PHYLIP package (Felsenstein, 1993). Genomic DNA was also used for PCR amplification of the nucleotide signature present in the 16S-23S rDNA region of members of the genus Kitasatospora, as described by Wang et al. (1996a, b).

Comparison of the almost complete 16S rRNA gene sequence of strain $52108 \mathrm{a}^{\mathrm{T}}$ with the corresponding sequences of the marker strains showed that the isolate belongs to the Kitasatospora clade (Fig. 1). This assignment was confirmed by the positive detection of the diagnostic PCR product in the 16S-23S rRNA gene spacer region of strain $52108 \mathrm{a}^{\mathrm{T}}$. The organism shared closest $16 \mathrm{~S}$ rRNA gene sequence similarity with the type strains of K. kifunensis $(99.0 \%), K$. arboriphila $(98.9 \%)$, K. paracochleata $(98 \cdot 4 \%)$ and K. terrestris (98.2\%). Lower 16S rRNA gene sequence similarities were found with the type strains of the remaining Kitasatospora species. DNA-DNA relatedness

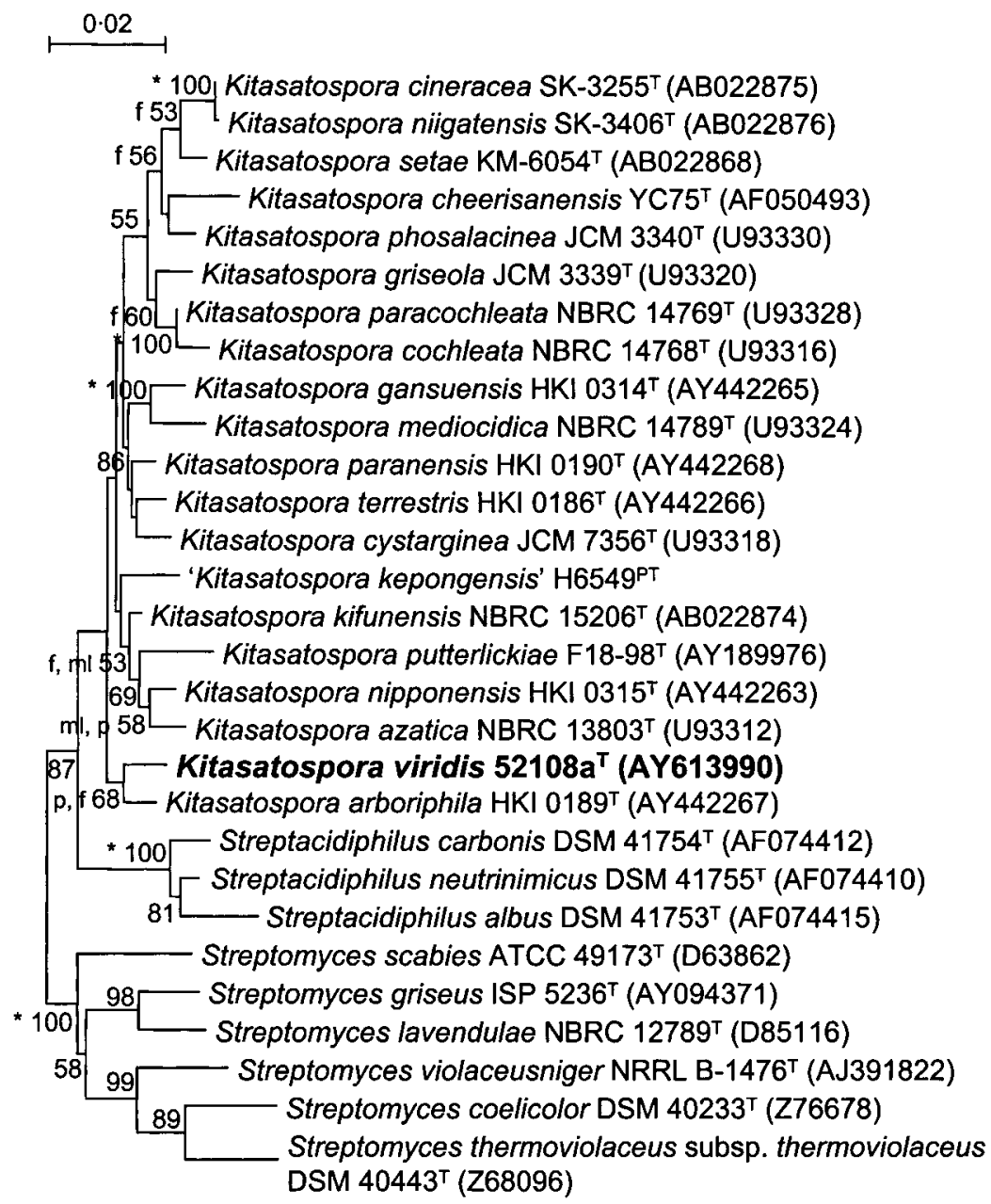

Fig. 1. Neighbour-joining tree based on nearly complete $16 \mathrm{~S}$ rRNA gene sequences showing the position of strain $52108 a^{\top}$ in the Kitasatospora tree. Asterisks indicate branches that were also recovered using the least-squares, maximum-likelihood and maximum-parsimony tree-making algorithms; $\mathrm{f}, \mathrm{ml}$ and $\mathrm{p}$ indicate branches that were formed using the least-squares, maximumlikelihood and maximum-parsimony algorithms, respectively. Numbers at nodes are percentage bootstrap values based on 1000 resampled datasets; only values above $50 \%$ are given. Bar, 0.02 nucleotide substitutions per nucleotide position. PT, Putative type strain (species name not yet validly published). 
studies were not carried out between strain $52108 \mathrm{a}^{\mathrm{T}}$ and its phylogenetically closest relatives as it has already been established that representatives of other Kitasatospora species with similar 16S rRNA gene sequence similarities, as exemplified by K. paranensis and K. terrestris (Groth et al., 2004), share DNA-DNA relatedness values well below the $70 \%$ cut-off point recommended for the delineation of bacterial species (Wayne et al., 1987). The tested strain can be distinguished from its phylogenetically nearest relatives using a combination of phenotypic properties (Table 1). It is proposed that strain $52108 \mathrm{a}^{\mathrm{T}}$ be assigned to the genus Kitasatospora as a novel species, with the name Kitasatospora viridis sp. nov.

\section{Description of Kitasatospora viridis sp. nov.}

Kitasatospora viridis (vi'ri.dis. L. fem. adj. viridis green, referring to the production of a green aerial spore mass).

Aerobic, Gram-positive, non-acid-alcohol-fast, non-motile actinomycete that forms an extensively branched, lightyellow substrate mycelium and a greenish aerial spore mass on acidified oatmeal agar. Aerial hyphae differentiate into long, spiral chains of smooth-surfaced, cylindrical spores $(1 \cdot 0-1 \cdot 2 \times 0 \cdot 7-0 \cdot 8 \mu \mathrm{m})$. Starch is degraded, but not adenine, guanine, hypoxanthine, xanthine or xylan. Adonitol, (+)-D-cellobiose, dextran, (+)-D-galactose, (-)-D-gluconic acid, (+)-D-glucose, inulin, (+)-D-lactose, $(+)$-D-maltose, $\quad(+)$-D-mannose, $\quad(+)$-D-melezitose, (+)-D-melibiose, (-)-D-salicin, (-)-D-sorbitol, ( +)-Dtrehalose and xylitol are used as sole carbon sources for energy and growth, but not glycerol, meso-inositol or xylan (all at $1 \%, w / v)$. Similarly, 2-aminoethanol, $\alpha$-DLaminobutyric acid, L-alanine, L-arginine, L-cysteine, Lglutamic acid, L-histidine, L-isoleucine, L-phenylalanine, L-threonine, L-valine, sodium oxalate and sodium pyruvate are used as sole carbon sources, but not adipic acid or L-aspartic acid (all at $0 \cdot 1 \%, \mathrm{w} / \mathrm{v}$ ). 2-Aminoethanol, L-alanine, L-arginine, L-isoleucine and L-phenylalanine are used as sole sources of carbon and nitrogen for energy and growth. Growth occurs at $10-37^{\circ} \mathrm{C}$, but not at 4 or $45^{\circ} \mathrm{C}$. The $\mathrm{pH}$ range for growth is $\mathrm{pH} 4-7 \cdot 0$. Growth occurs in the presence $\left(\mu \mathrm{g} \mathrm{ml}^{-1}\right)$ of amikacin (32), amoxicillin (32), ampicillin (32), cefalexin (32), cephaloridine (64), clindamycin (8), doxycycline hydrochloride (32), fusidic acid (16), gentamicin sulphate (16), kanamycin sulphate

Table 1. Phenotypic properties that separate strain $52108 \mathrm{a}^{\top}$ from representatives of closely related Kitasatospora species

Taxa: 1, strain $52108 \mathrm{a}^{\mathrm{T}}$; 2, K. arboriphila HKI $0189^{\mathrm{T}}$ (data from Groth et al., 2004); 3, K. kifunensis DSM 41654 ${ }^{\mathrm{T}}$ (Groth et al., 2004); 4, K. paracochleata DSM 41656 ${ }^{\mathrm{T}}$ (Nakagaito et al., 1992); 5, K. terrestris HKI 0186 ${ }^{\mathrm{T}}$ (Groth et al., 2004). All are positive for $(+)$ )-D-xylose. + , Positive/present; -, negative/absent; (+), weakly positive; NA, not analysed.

\begin{tabular}{|c|c|c|c|c|c|}
\hline Characteristic & 1 & 2 & 3 & 4 & 5 \\
\hline Spore chain morphology ${ }^{\star}$ & $\mathrm{S}$ & RA, RF, S & $\mathrm{RF}, \mathrm{S}$ & S & RA, RF, S \\
\hline Melanoid pigments & - & + & + & + & + \\
\hline \multicolumn{6}{|l|}{ Growth at: } \\
\hline $10^{\circ} \mathrm{C}$ & - & - & $(+)$ & - & - \\
\hline $37^{\circ} \mathrm{C}$ & + & + & - & - & + \\
\hline $3 \cdot 0$ & + & - & - & - & $(+)$ \\
\hline $3 \cdot 5$ & + & - & - & - & - \\
\hline \multicolumn{6}{|l|}{$\mathrm{pH}$ for growth: } \\
\hline $4 \cdot 0$ & + & - & - & $+\dagger$ & - \\
\hline $8 \cdot 0$ & - & + & + & NA & + \\
\hline$(+)$-L-Rhamnose & + & - & - & + & $(+)$ \\
\hline$(-)$-D-Sucrose & + & - & + & + & $(+)$ \\
\hline \multicolumn{6}{|l|}{ Resistance to antibiotics $\left(\mu \mathrm{g} \mathrm{ml}^{-1}\right)$ : } \\
\hline Ampicillin (10) & + & - & $(+)$ & NA & - \\
\hline Lincomycin hydrochloride (2) & + & - & - & + & - \\
\hline Novobiocin (5) & - & + & + & + & + \\
\hline Penicillin G (10 IU) & + & - & - & + & - \\
\hline
\end{tabular}

${ }^{*} \mathrm{RA}$, Retinaculiaperti; RF, rectiflexibiles; S, spirales.

$\dagger$ Data from this study. 
(16), lincomycin hydrochloride (16), midecamycin (4), neomycin sulphate (32), penicillin G (16 IU), streptomycin sulphate (16), tetracycline hydrochloride (32) and tobramycin sulphate (16), but is inhibited by erythromycin (8) and novobiocin (8). Sodium chloride is tolerated up to a concentration of $10 \%(\mathrm{w} / \mathrm{v})$. Additional phenotypic properties are listed in Table 1. Cell wall contains both mesoand LL-diaminopimelic acid and $\mathrm{N}$-acetylated muramic acid, and whole-organism hydrolysates are rich in galactose and glucose. The major polar lipids are diphosphatidylglycerol, phosphatidylethanolamine, phosphatidylinositol and phosphatidylinositol mannosides. The predominant isoprenologues are hexa- $(76 \%)$ and octa- $(17 \%)$ hydrogenated menaquinones with nine isoprene units. The major fatty acids are iso- $\mathrm{C}_{15: 0}(19 \%)$, anteiso- $\mathrm{C}_{15: 0}(18 \%)$, iso$\mathrm{C}_{16: 0}(18 \%), \mathrm{C}_{16: 0}(22 \%)$ and anteiso- $\mathrm{C}_{17: 0}(8 \cdot 0 \%)$.

The type strain, $52108 \mathrm{a}^{\mathrm{T}}\left(=\right.$ AS $\left.4.1878^{\mathrm{T}}=\mathrm{DSM} 44826^{\mathrm{T}}\right)$, was isolated from a soil sample taken from the roots of Camellia oleifera in Jiangxi Province, China.

\section{Acknowledgements}

This work was supported through the Royal Society-Chinese Academy of Sciences Exchange Scheme (grant no. Q 814). C.R. gratefully acknowledges receipt of a studentship from the Ecuadorian FUNDACYT (Foundation for Science and Technology) and an Overseas Research Studentship Award (UK). E.T.Q. gratefully acknowledges the financial support provided by the Consejo Nacional de Ciencia y Tecnología (CONACyT, Mexico City, Mexico) and an Overseas Research Studentship Award (UK). We are also indebted to Professor Gao Yongsheng for providing the soil samples.

\section{References}

Chun, J. (1995). Computer-assisted classification and identification of actinomycetes. $\mathrm{PhD}$ thesis, University of Newcastle, UK.

Chung, Y. R., Sung, K. C., Mo, H. K., Son, D. Y., Nam, J. S., Chun, J. \& Bae, K. S. (1999). Kitasatospora cheerisanensis sp. nov., a new species of the genus Kitasatospora that produces an antifungal agent. Int J Syst Bacteriol 49, 753-758.

Collins, M. D. (1985). Isoprenoid quinone analyses in bacterial classification and identification. In Chemical Methods in Bacterial Systematics, pp. 267-287. Edited by M. Goodfellow \& D. E. Minnikin. London: Academic Press.

Felsenstein, J. (1993). PHYLIP (Phylogeny Inference Package), version 3.5c. Distributed by the author. Department of Genetics, University of Washington, Seattle, USA.

Groth, I., Schütze, B., Boettcher, T., Pullen, C. B., Rodriguez, C., Leistner, E. \& Goodfellow, M. (2003). Kitasatospora putterlickiae sp. nov., isolated from rhizosphere soil, transfer of Streptomyces kifunensis to the genus Kitasatospora as Kitasatospora kifunensis comb. nov., and emended description of Streptomyces aureofaciens Duggar 1948. Int J Syst Evol Microbiol 53, 2033-2040.

Groth, I., Rodríguez, C., Schütze, B., Schmitz, P., Leistner, E. \& Goodfellow, M. (2004). Five novel Kitasatospora species from soil: Kitasatospora arboriphila sp. nov., $K$. gansuensis sp. nov., $K$. nipponensis sp. nov., $K$. paranensis sp. nov. and $K$. terrestris sp. nov. Int J Syst Evol Microbiol 54, 2121-2129.
Hasegawa, T., Takizawa, M. \& Tanida, S. (1983). A rapid analysis for chemical grouping of aerobic actinomycetes. J Gen Appl Microbiol 29, 319-322.

Hopwood, D. A., Bibb, M. J., Chater, K. F. \& 7 other authors (1985). Genetic Manipulation of Streptomyces. A Laboratory Manual. Norwich: The John Innes Foundation.

Huang, Y., Cui, Q., Wang, L., Rodriguez, C., Quintana, E., Goodfellow, M. \& Liu, Z. (2004). Streptacidiphilus jiangxiensis sp. nov., a novel actinomycete isolated from acidic rhizosphere soil in China. Antonie van Leeuwenhoek 86, 159-165.

Jones, K. L. (1949). Fresh isolates of actinomycetes in which the presence of sporogenous aerial mycelia is a fluctuating characteristic. $J$ Bacteriol 57, 141-145.

Kämpfer, P. \& Kroppenstedt, R. M. (1996). Numerical analysis of fatty acid patterns of coryneform bacteria and related taxa. Can J Microbiol 42, 989-1005.

Kawato, M. \& Shinobu, R. (1959). On Streptomyces herbaricolor nov. sp. Supplement: a simple technique for the microscopic observation. Mem Osaka Univ Lib Arts Educ 8, 114-119.

Kim, S. B., Falconer, C., Williams, E. \& Goodfellow, M. (1998). Streptomyces thermocarboxydovorans $\mathrm{sp}$. nov. and Streptomyces thermocarboxydus sp. nov., two moderately thermophilic carboxydotrophic species from soil. Int J Syst Bacteriol 48, 59-68.

Kusakabe, H. \& Isono, K. (1992). Kitasatosporia cystarginea sp. nov. In Validation of the Publication of New Names and New Combinations Previously Effectively Published Outside the IJSB, List no. 41. Int J Syst Bacteriol 42, 327-328.

Küster, E. (1959). Outline of a comparative study on criteria used in characterisation of the actinomycetes. Int Bull Bacteriol Nomencl Taxon 9, 97-104.

Labeda, D. P. (1988). Kitasatosporia mediocidica sp. nov. Int J Syst Bacteriol 38, 287-290.

Minnikin, D. E., O'Donnell, A. G., Goodfellow, M., Alderson, G., Athalye, M., Schaal, A. \& Parlett, J. H. (1984). An integrated procedure for the extraction of bacterial isoprenoid quinones and polar lipids. J Microbiol Methods 2, 233-241.

Nakagaito, Y., Yokota, A. \& Hasegawa, T. (1992). Three new species of the genus Streptomyces: Streptomyces cochleatus sp. nov., Streptomyces paracochleatus sp. nov., and Streptomyces azaticus sp. nov. J Gen Appl Microbiol 38, 105-120.

Nakagaito, Y., Shimazu, A., Yokota, A. \& Hasegawa, T. (1993a). Streptomyces cochleatus sp. nov., Streptomyces paracochleatus sp. nov. and Streptomyces azaticus sp. nov. In Validation of the Publication of New Names and New Combinations Previously Effectively Published Outside the IJSB, List no. 44. Int J Syst Bacteriol 43, 188-189.

Nakagaito, Y., Shimazu, A., Yokota, A. \& Hasegawa, T. (1993b). Streptomyces kifuensis sp. nov. In Validation of the Publication of New Names and New Combinations Previously Effectively Published Outside the IJSB, List no. 46. Int J Syst Bacteriol 43, 624.

O'Donnell, A. G., Falconer, C., Goodfellow, M., Ward, A. C. \& Williams, E. (1993). Biosystematics and diversity amongst novel carboxydotrophic actinomycetes. Antonie van Leeuwenhoek 64, 325-340.

Ōmura, S., Takahashi, Y., Iwai, Y. \& Tanaka, H. (1982). Kitasatosporia, a new genus of the order Actinomycetales. J Antibiot 35, 1013-1019.

Ōmura, S., Takahashi, Y., Iwai, Y. \& Tanaka, H. (1983). Kitasatosporia setalba sp. nov. In Validation of the Publication of New Names and New Combinations Previously Effectively Published Outside the IJSB, List no. 11. Int J Syst Bacteriol 33, 672-674.

Ōmura, S., Takahashi, Y., Iwai, Y. \& Tanaka, H. (1985). Revised nomenclature of Kitasatosporia setalba. Int J Syst Bacteriol 35, 221. 
Reed, J. F. \& Cummings, R. W. (1945). Soil reaction-glass electrodes and colorimetric methods for determining $\mathrm{pH}$ value of soil. Soil Sci 59, 97-104.

Sasser, M. (1990). Identification of bacteria by gas chromatography of cellular fatty acids. Technical Note 101. Newark, DE: MIDI Inc.

Staneck, J. L. \& Roberts, G. D. (1974). Simplified approach to identification of aerobic actinomycetes by thin layer chromatography. Appl Microbiol 28, 225-231.

Tajima, K., Takahashi, Y., Seino, A., Iwai, Y. \& Ōmura, S. (2001). Description of two novel species of the genus Kitasatospora Ōmura et al. 1982, Kitasatospora cineracea sp. nov. and Kitasatospora niigatensis sp. nov. Int J Syst Evol Microbiol 51, 1765-1771.

Takahashi, Y., Iwai, Y. \& Ōmura, S. (1985). Kitasatosporia griseola sp. nov. In Validation of the Publication of New Names and New Combinations Previously Effectively Published Outside the IJSB, List no. 19. Int J Syst Bacteriol 35, 535.

Uchida, K. \& Aida, K. (1977). Acyl type of bacterial cell wall: its simple identification by colorimetric method. J Gen Appl Microbiol 23, 249-260.

Van de Peer, Y. \& De Wachter, R. (1994). TREECON for Windows: a software package for the construction and drawing of evolutionary trees for the Microsoft Windows environment. Comput Appl Biosci 10, 569-570.

Wang, Y., Zhang, Z. \& Ruan, J. (1996a). Phylogenetic analysis reveals new relationships among members of the genera Microtetraspora and Microbispora. Int J Syst Bacteriol 46, 658-663.
Wang, Y., Zhang, Z. \& Ruan, J. (1996b). A proposal to transfer Microbispora bispora (Lechevalier 1965) to a new genus, Thermobispora gen. nov., as Thermobispora bispora comb. nov. Int J Syst Bacteriol 46, 933-938.

Wang, L., Cui, Q., Huang, Y., Xie, Q., Zhang, Y. \& Liu, Z. (2003). Isolation of acidophilic and acidoduric streptomycetes using a dispersion and differential centrifugation approach. Microbiology (English translation of Mikrobiologiya) 30, 104-106.

Wayne, L. G., Brenner, D. J., Colwell, R. R. \& 9 other authors (1987). Report of the ad hoc committee on reconciliation of approaches to bacterial systematics. Int J Syst Bacteriol 37, 463-464.

Wellington, E. M. H., Stackebrandt, E., Sanders, D., Wolstrup, J. \& Jorgensen, N. O. G. (1992). Taxonomic status of Kitasatosporia, and proposed unification with Streptomyces on the basis of phenotypic and 16S rRNA analysis and emendation of Streptomyces Waksman and Henrici $1943,339^{\mathrm{AL}}$. Int J Syst Bacteriol 42, 156-160.

Williams, S. T., Goodfellow, M., Alderson, G., Wellington, E. M. H., Sneath, P. H. A. \& Sackin, M. J. (1983). Numerical classification of Streptomyces and related genera. J Gen Microbiol 129, 1743-1813.

Wu, C., Lu, X., Qin, M., Wang, Y. \& Ruan, J. (1989). Analysis of menaquinone compounds in microbial cells by HPLC. Microbiology (English translation of Mikrobiologiya) 16, 176-178.

Zhang, Z., Wang, Y. \& Ruan, J. (1997). A proposal to revive the genus Kitasatospora (Omura, Takahashi, Iwai, and Tanaka 1982). Int J Syst Bacteriol 47, 1048-1054.

Zhou, Z.-H., Liu, Z.-H., Qian, Y.-D., Kim, S. B. \& Goodfellow, M. (1998). Saccharopolyspora spinosporotrichia sp. nov., a novel actinomycete from soil. Int J Syst Bacteriol 48, 53-58. 